\title{
Development on the leading small and medium-sized industry (SMI): food industry in Jambi Province
}

\author{
Sesraria Yuvanda ${ }^{1 *}$; M. Rachmad.R ${ }^{2}$ Zamzami $^{3}$; M. Safri ${ }^{4}$ \\ ${ }^{1)}$ Development Economics Department, Faculty of Economics and Business, \\ Universitas Muhammadiyah Jambi, Indonesia \\ 2), 3), 4) Development Economics Department, Faculty of Economics and Business, \\ Universitas Jambi, Indonesia
}

*To whom correspondence should be addressed.Email: sesraria@gmail.com

\begin{tabular}{|l|l|l|l|l|}
\hline DOI: & Received: & Revised: & Accepted: & Published: \\
10.22437/ppd.v8i3.9868 & 06.07 .2020 & 10.08 .2020 & 12.08 .2020 & 31.08 .2020 \\
\hline
\end{tabular}

\begin{abstract}
The objectives of this research are: 1). to analyze the factors which determine the production of leading small-medium food industry, 2). to analyze the effect of leading small-medium food industry production towards community income. The analysis models used are simultaneous equation model (ESM) and simple regression. The research results show that the determining factors on the production of leading smallmedium food industry are investment, production capacity, labor, sales, and the utilization of technology simultaneously. However, individually, the sales have significant influence on the production of leading small-medium food industry in which determined by promotion and market share. In addition, the influence of leading smallmedium food industry is very significant on community income with a contribution of $59.54 \%$. The amount of public income in the leading small-medium food industry is IDR 1.5 million for a single production period of 1.5 months or approximately IDR 1 million per month.
\end{abstract}

Keywords: Food, Industry, Income

JEL Classification: D24, O14, L66

\section{INTRODUCTION}

In the era of globalization, the level of competitiveness has been a definite benchmark in realizing free market competition in both the activities and trade of the world economy which is the principal of market forces. The development of competitiveness on a national and international scale is closely related to the level of competitiveness at the regional level (Jayanti \& Musqorobin, 2017)

Industry is an economic activity that processes raw materials, semi-processed, or finished goods into high-value goods. Meanwhile, food is anything that comes from biological sources and water, whether processed or not processed and intended as food or drink for human consumption. These include food additives, food raw materials and, other materials used in the process of preparing, processing, and manufacturing food or drinks (Sobari, 2018). 
At the macro level, the manufacturing sector is still the biggest contributor to the national economic structure. The contribution of the manufacturing sector to the Gross Domestic Product in 2019 is seen to be $19.52 \%$. As for Jambi Province, the contribution of the manufacturing industry to the Gross Regional Domestic Product was $6.36 \%$. This means that the contribution in processing industry in Jambi Province is less than the national contribution. Developing the manufacturing industry is therefore required to support regional economic development and expand employment and business opportunities.

In developing industrialization in the regions, the role of small and medium-sized industries is very significant. Data in 2018 shows that there are 30,456 units of Small and Medium-sized Industries in Jambi Province with an employment of 119,902 people and an investment value of 5,527,603,732 IDR. The existence of this small and medium-sized industry is crucial because it is capable of generating employment and encouraging investment growth in Jambi Province. Meirejeki (2016) states that it is necessary to select the industrial sector to determine which industries can be the leading sector as the basis for development.

As demonstrated by the number of small and medium-sized industries in Jambi Province as many as 30,456 units, the majority of these industries are dominated by the food industry. The food industry has a business unit of 11,917 units or $39.64 \%$ of the population of the small and medium industry in Jambi Province. The distribution of data for small and medium-sized industries in Jambi Province is based on Indonesian Standard Industrial Classification (ISIC) as described in the table below.

Table 1. Classification of Small-Medium Industry (SMI) in Jambi Province, 2018

\begin{tabular}{lcr}
\hline Class & Number of unit & $(\%)$ \\
\hline Food & 11,917 & 39.64 \\
Clothing & 2,921 & 9.72 \\
Metals and Electronics & 3,976 & 13.23 \\
Chemical and Building Materials & 7,528 & 25.05 \\
Crafts & 3,714 & 12.36 \\
\hline Total & 30,056 & 100.00 \\
\hline
\end{tabular}

Source: Department of Industry and Trade, Jambi Province 2019

Table 1 illustrates the dominance of the food industry in Jambi Province in small and medium-sized industries. The chemical industry and building materials industry ranks second with 7,528 units or $25.05 \%$. The food industry is noteworthy because it contributes $39.64 \%$ to the development of small and medium-sized industries in Jambi Province.

Specifically, the Jambi Province Department of Industry and Trade indicated that 115 units of leading food industries had been identified in Jambi Province. The food industries are then divided into five groups, as seen in the Table 2.

Table 2. Classification of Small-Medium Food Industry (SMI) in Jambi Province, 2018

\begin{tabular}{lcc}
\hline Class & Number of unit & $(\%)$ \\
\hline Bulbs & 7 & 6.36 \\
Fruits & 26 & 23.64 \\
Plantation Products & 24 & 21.82 \\
Seafood & 20 & 18.18 \\
Nuts & 33 & 30.00 \\
\hline Total & 110 & 100.00 \\
\hline
\end{tabular}

Source: Department of Industry and Trade, Jambi Province 2019 
In the development of the leading small and medium-sized food industries, production is also determined and it will entail the right strategy to accelerate the growth of the industry itself. Several factors can affect the industry, including investment, production capacity, labor, sales and use of technology. This theory is in accordance with the results of the research conducted by Yuvanda \& Rosita (2018) which stated that investment and price variables affect the production of superior plantations. These factors will be input in developing small and medium-sized food industries. Determinant factor for small and medium-sized food industries is therefore required.

A strategy needs to be established from the acquisition of factors as the determinants of production of leading small and medium-sized food industry. The strategy seeks to ensure that the leading small and medium-sized food industry can accelerate the growth of leading small and medium-sized food industry. Guine, Ramalhosa \& Valente (2016) who conducted research in Portugal with the title "New Foods, New Consumers: Innovation in Food Product Development" states that in the development of the food industry, products and processes are considered an important part of smart business strategies. The food industry must innovate in the area of production technology.

In addition, the growth of the leading small and medium food industry would also increase the added value of the industrial community. Increased public income is reflected in the rise in income as a factory owner, an increase in wages for labor, and profits as a business owner and the acquisition of margins in the input supply chain and product sales chain generated by the leading small and medium-sized food industry.

Based on the explanation given above, the objectives of this study are as: 1) to analyze the factors which decide the production of the leading small and medium-sized food industry; 2) to analyze the effect of the production of the leading small and medium-sized food industry on community income.

\section{METHODS}

The data to be used is derived from secondary data. The secondary data used came from the Jambi Province Industry and Trade Office. Based on the data, there are 110 small and medium-sized food industries in 2019.

Simultaneous Equation Model is used to responde to the first research objective, which is to determine factors that influence the development of small and mediumsized food industries identified as superior. Simultaneous equation model explores the relationship of independent variables to other variables.

This statistical model is used to avoid bias, inconsistency, and inefficiency when the ordinary least square is used. The multiple regression equation model is then estimated using Two Stage Least Square (TSLS). TSLS can solve the issue of bias, inconsistency, and inefficiency through 2 phases of calculation including:

Phase-I : Regressing independent variables with predetermined variables:

$$
\mathrm{X}_{1}=\mathrm{f}\left(\mathrm{X}_{1.1}, \mathrm{X}_{1.2}, \ldots \mathrm{X}_{1.4}\right) \text { and } \mathrm{X}_{2}=\mathrm{f}\left(\mathrm{X}_{2.1}, \mathrm{X}_{2.2}, \ldots . \mathrm{X}_{2.3}\right)
$$

Phase-II : Regresses the dependent variable by estimating the independent variable:

$$
\mathrm{Y}=\mathrm{f}\left(\mathrm{X}_{1}, \mathrm{X}_{2}, \mathrm{X}_{3} \ldots \ldots \ldots \ldots \mathrm{X}_{8}\right)
$$

Mathematically, the factors that influence the production of the leading small and medium-sized food industries are formulated as follows:

$$
\text { PDS }=a_{0}+a_{1} I V S+a_{2} \mathrm{KPP}+\mathrm{a}_{3} \widehat{\mathrm{TKJ}}+\mathrm{a}_{4} \mathrm{PGT}+\mathrm{a}_{5} \mathrm{PJL}+\mathrm{u}_{1}
$$




$$
\begin{aligned}
& \overparen{\mathrm{KPP}}=\mathrm{b}_{0}+\mathrm{b}_{1} \mathrm{IVS}+\mathrm{b}_{2} \mathrm{PGT}+\mathrm{u}_{2} \\
& \mathrm{PJL}=\mathrm{c}_{0}+\mathrm{c}_{1} \mathrm{PPS}+\mathrm{c}_{2} \mathrm{BPM}+\mathrm{u}_{3}
\end{aligned}
$$

PDS : Production of the leading Small and medium-sized food industry

IVS : Investment

KPP : Production capacity

TKJ : Labor

PGT : Technology Utilization

PJL : Sales

PPS : Market share

BPM : Promotion Fee

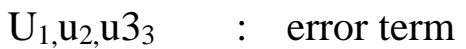

a,b,c : regression coefficient

A simple regression model is used to meet the second research objective by analyzing the effects of the leading small and medium-sized food industry on community income using the following mathematical equations;

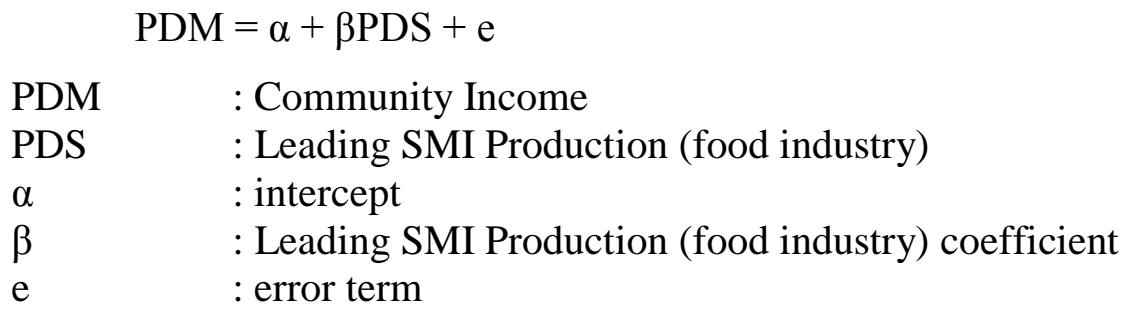

From the formulation of the two models above, the variables used in the model can be operationalized. As for the operations, they are referred to:

1. Production is the total value of goods produced by the medium-sized, superior food industry, resulting from the production process of the industry in order to increase the added value measured in rupiah for one time production.

2. Investment is the amount of funds used for the development of superior small and medium-sized food industry businesses in order to gain profits measured in rupiah per year.

3. Production capacity is the maximum production that can be achieved from equipment used to produce goods by small and medium-sized food industry, measured in kilograms per year.

4. Manpower is the number of people who work for one time production in the small and medium-sized food industry.5. Use of technology is the amount of funds used by superior small and medium-sized food industries to purchase technology in the manufacturing process, measured in rupiah per year.

6. Sales are revenues generated by the leading small and medium-sized food industry from the sale of their goods, measured in rupiah per year.

7. Market share is the size of the market dominated by the leading small and mediumsized food industry in marketing their goods, measured in percentage $(\%)$ per year.

8. Promotion costs are funds spent on the promotion of goods produced by the leading small and medium-sized food industries, measured in rupiah units per year.

9. Community income is the salary/wages earned by the community for their work in the leading small and medium-sized food industry, measured in rupiah per month. 


\section{RESULTS AND DISCUSSION}

The average production value for the 110 leading small and medium-sized food business units is 2.91 billion. The coffee processing industry has the largest average production, approximately 13.02 billion, while the average investment value is 49.89 million, with the marine fishery processing industry having the largest investment of 427.53 million. The average installed production capacity is $12,580.55 \mathrm{~kg}$, with the coffee processing industry having the largest production capacity with an estimated production capacity of $21,900 \mathrm{~kg}$. In addition, the leading small and medium-sized food industry can absorb an average of 5 workers per business unit with a total absorption capacity of 528 people for all industries.

On the other hand, the leading small and medium-sized food industries have total sales of 17.59 billion, with an average sale of 159.87 million for each business unit, while the marine fishery product processing industry has the largest sales with an average sale of 230.21 million. Meanwhile, for the overall use of technology, each business unit uses technology valued at 62.35 million, with the tuber processing industry providing the largest technology usage value, approximately 26.39 million. In terms of the market share, the tuber processing industry has the largest average market share of $14.29 \%$ and the legume processing industry only has an average market share of $3.03 \%$. Meanwhile, the average promotional costs of the leading small and mediumsized industry is 10.82 million, with the coffee processing industry spending the most promotional costs of 21.20 million.

To analyze the determinants of production of the leading small and medium-sized industries (SMI), a simultaneous equation analysis model is used. Simultaneous equation uses 2 stages of analysis to generate a simultaneous equation.

\section{First Analysis}

\section{Phase 1}

Phase 1 analyzes the effect of investment (IVS) and the use of technology (PGT) on production capacity (KPP). The results of data processed by Eviews program are outlined in the following regression equation.

$$
\begin{array}{llcc}
\text { KPP } & =2468,920-0,000370 \mathrm{IVS} & +0,001557 \mathrm{PGT}+\mathrm{e} \\
\mathrm{Prob} & = & (0,0000) & (0,0000) \\
\mathrm{R}^{2}=0.370826 & &
\end{array}
$$

Overall, the investment factor (IVS) and the use of technology (PGT) have a significant effect on production capacity (KPP) at $\mathrm{P}=0.092135$. While partially, these two factors also have a significant effect on production capacity (KPP), each at $\mathrm{P}=$ 0.0000. This means that investment (IVS) and the use of technology (PGT) both overall and partially greatly affect the production capacity at $\mathrm{R}^{2}=0.370826$.

\section{Phase 2}

Phase 2 analyzes the effect of market share (PPS) and promotion costs (BPM) on sales (PES). The results of data processing are outlined in the following form of regression equation.

$$
\begin{array}{lll}
\text { PES } & =-21830777+5178518 P P S+14,61771 \mathrm{BPM}+\mathrm{e} \\
\text { Prob } & = & (0,0063)
\end{array}
$$

Overall, market share (PPS) and promotion costs (BPM) have a very significant effect $(\mathrm{P}=0.0000)$ on sales (PES). While partially, both of these factors also have a very significant effect on sales (PES), each probability value is $\mathrm{P}=0.0063$ and $\mathrm{P}=$ 
0.0000. Means that market share (PPS) and promotion costs (BPM) both have a very significant effect on sales (PES).

The effect of promotion on sales was also found in various previous studies, including Baidya \& Ghose (2010), Darmadi, Suharyono, Latief (2013), Jasmani (2018). The promotion center will also be a hub for innovation for product development. Innovation is very important in the product development of the small and medium-sized industries (Saguy \& Sirotinskaya, 2014)

\section{Second analysis}

The second stage of the analysis was carried out to analyze the influence of investment factors (IVS), production capacity (KPP), labor (TKJ), sales (PES), and the use of technology (PGT) on production (PDS) of leading food SMIs. The analysis in the second stage is carried out with the help of EViews. The results are outlined in the following regression equation.

$$
\begin{aligned}
& \text { PDS }=-35394341-1,849 \mathrm{IVS}-5075,919 \mathrm{KPP}+9363172 \mathrm{TKJ}+0,512 \mathrm{PJL}+9,032 \mathrm{PGT}+\mathrm{e} \\
& \text { Prob }=\quad(0,0988) \quad(0,0636) \quad(0,1075) \quad(0,000) \quad(0,0564) \\
& \mathrm{KPP}=2468,920-0,000370 \mathrm{IVS}+0,001557 \mathrm{PGT}+\mathrm{e} \\
& \text { Prob }=(0,0000) \quad(0,0000) \\
& \mathrm{PJL}=-21830777+5178518 \mathrm{PPS}+14,61771 \mathrm{BPM}+\mathrm{e} \\
& \text { Prob }=(0,0063) \quad(0,0000)
\end{aligned}
$$

Overall, investment factors (IVS), production capacity (KPP), labor (TKJ), sales (PES), and use of technology (PGT) have a very significant effect $(\mathrm{P}=0.0000)$ on production (PDS). The contribution value of all factors affecting production (PDS) is $84.615 \%$ or $\mathrm{R}^{2}=0.846150$

While partially, all of these factors also have a significant effect on production (PDS) but the probability varies. The sales factor (PES) has a probability $\mathrm{P}=0.0000$, meaning that sales have a very significant effect on individual sales. Investment (IVS) $\mathrm{P}=0.0988$, labor $(\mathrm{TKJ}) \mathrm{P}=0.1075$, production capacity $(\mathrm{KPP}) \mathrm{P}=0.0636$, and the use of technology (PGT) $\mathrm{P}=0.0564$ has a significant effect on sales (PES ). This means, sales (PES) is very influential on the production of leading food industry, followed by the factor of technology use (PGT) and production capacity (KPP) which also influence the sales (PES).

The findings of this research are also aligned with the results of the research conducted by Hidayat (2005) which indicates that labor and investment have a significant effect on industrial development. However, there are also differences in findings as this research favored the sales factor as the greatest effect on production. Meanwhile, the results of research Hidayat (2005) favored the labor factor as the greatest effect on production. Furthermore, the influence of technology on production found in this study is also in line with several previous studies including Prakash \& Sharma (2011), Ketema \& Kassa (2016), Fauzi, Amir, Junaidi \& Hidayat (2019)

In another part of the research findings, Hidayat \& Rasjid (2019) also affirm the results of this study which indicate that labor affects the production of small and medium-sized industries. The results of this research are also supported by the results of research of Wibowo \& Nugroho (2018) which states that labor also has a significant positive effect on industrial production.

In order to analyze the effect of the production of the leading small and mediumsized industries (SMI) on community income, a simple regression analysis model is used. The results of data processing are outlined in the following simple regression equation. 


$$
\begin{array}{llc}
\text { PDM } & =353599,7+0,012985 P D S \\
\text { Prob } & = & (0,0000)
\end{array}
$$

The equation above shows that the production (PDS) of the leading food industry has a very significant effect on community income (PDM) at R2 $=0.595389$. This means that the production of the leading food industry (PDS) has contributed to the income of those working in the sector (PDM) of 59.54\%. This is understandable because the income is earned by working part time in the leading food industry sector and the majority are women or housewives.

The average income of people employed in the leading food industry is IDR 1.5 million for a single production period of 1.5 months for the leading food industry. This is equal to monthly community income of IDR 1 million. This figure is still far from the provincial minimum wage that has reached IDR 2.4 million. The results of this research show the significant impact of the production of the leading small and medium-sized food industry on the income of the surrounding community as industrial workers.

The results of the research above indicate that it is in line with the results of research by Hidayat (2005) which states that industrial development through the export agro-industrial commodity approach has an impact on income. The findings of this study also show that the development of the leading small and medium-sized food industry has an impact on the income of the surrounding community as industrial workers.

\section{CONCLUSIONS AND RECOMMENDATIONS}

\section{Conclusions}

Determinants of the leading small and medium-sized industrial (SMI) production are investment, production capacity, labor, sales and use of technology. However, individually, sales factors greatly influence the production of the leading food industries with promotion and market share as the two main keys.

The leading food industry production has a very significant influence on community income with a share of $59.54 \%$. The amount of income earned by the people employed in the leading small and medium-sized food industry (SMI) is IDR 1.5 million for a single production period of 1.5 months or approximately IDR 1 million per month.

\section{Recommendations}

Developing a center for the promotion of leading food SMIs products through online and offline. To go online, a multimedia center promotion needs to be encouraged and planned to proceed so that online shopping services can be offered to the leading food SMI entrepreneurs. As for offline promotion, partnership with malls and supermarkets/minimarkets is required for the leading retailers of leading food SMI products with minimal costs.

Building a technology design center for products and leading modern high school food products that allowing them to produce up-to-date and high-quality products with low cost of production so that the selling price can be competitive.

\section{REFERENCES}

Baidya, M.K \& Ghose, K. (2010). Effectiveness of sales promotion effort in emerging markets: a brand level analysis. International Journal of Business and Emerging Markets, 2(1), pages 43-57. 
Darmadi, D., Suharyono, Latief, W.A. (2013). Pengaruh Promosi Penjualan terhadap Penjualan (Kasus PT. Astra Internasional Tbk-TSO Cabang Soetoyo Malang). Jurnal Administrasi Bisnis, 2(1), 21-28

Fauzi, A., Amir, A., Junaidi, J. \& Hidayat, S. (2019). Change of Economic Structure in Jambi Province: Input-Output Model Approach. Scientific Research Journal, 7(8), $62-72$

Guine, R.P.F., Ramalhosa, E.C.D., \& Valente, L.P. (2016). New Foods, New Consumers: Innovation in Food Product Development. Current Nutrition and Food Science. 12(3), 175-189

Hidayat, M.S. (2005). Analisis Pengembangan Industri Melalui Pendekatan Komoditas Agroindustri Ekspor dan Pengaruhnya terhadap Penggunaan Tenaga Kerja dan Pendapatan di Provonsi Jambi. (Unpublished doctoral dissertation). Universitas Padjadjaran, Bandung

Hidayat, M.S \& Rasjid, M.R (2019). Policy Analysis On Development Of Leading Creative Industry Products In Muara Bungo Regency. International Journal of Scientific \& Technology Research, 8(11), 1941-1944

Jasmani (2018). Pengaruh Promosi dan Pengembangan Produk terhadap Peningkatan Hasil Penjualan. Jurnal Semarak, 1(3), 142-157

Jayanti, P.T \& Musqorobin, M. (2017). Analisis Strategi dan Program Peningkatan Daya Saing Pada Industri Unggulan Provinsi Jawa Tengah Dalam Menghadapi Masyarakat Ekonomi ASEAN (MEA). Jurnal Ekonomi dan Studi Pembangunan, 18(1), 52-61

Ketema, M. \& Kassa, B. (2016). Impact of Technology on Smallhoder Wheat Prodution in Bale Highlands of Ethiopia: Application of Outpur Decomposition Model. Turkish Journal of Agriculture - Food Science and Technology, 4(6), 446-454

Meirejeki, I, N. (2016). Pemilihan Industri Unggulan Sebagai Dasar Pengembangan Industri Kerajinan di Kabupaten Jembrana. Jurnal Bisnis dan Kewirausahaan, 12(1), 74-82.

Prakash, S. \& Sharma, R. (2011). Impact of Technology on Production in Indian Economy. International Conference on Education, Research and Innovation, 18, 77-83

Saguy, I.S. \& Sirotinskaya V. (2014). Challenges in exploiting open innovation's full potential in the food industry with a focus on small and medium enterprises (SMEs). Trends Food Science \& Technology, 38(2), 136-148

Sobari, E. (2018). Teknologi Pengolahan Pangan: Prinsip dan Praktik. Yogyakarta: Penerbit Andi

Wibowo, S.A. \& Nugroho, S.B.M. (2018). Analisis Faktor-faktor yang mempengaruhi produksi Industri Pengolahan dan Efisiensi Produksi pada Kabupaten/Kota di Jawa Tengah tahun 2010-2015. Jurnal Media Ekonomi dan Manajemen, 33(2), 205-213.

Yuvanda, S. \& Rosita, R. (2018). Analisis Produk Perkebunan Rakyat Unggulan Dan Dampaknya Terhadap Daya Serap Tenaga Kerja Untuk Pengentasan Kemiskinan Di Kabupaten Batanghari. Jurnal Development, 6(2), 105-115. 